\title{
Transport of AOPP-Albumin into Human Alveolar Epithelial A549 Cells
}

Masashi Kawami, Tadashi Shimonakamura, Ryoko Yumoto, Mikihisa Takano.

Department of Pharmaceutics and Therapeutics, Graduate School of Biomedical \& Health Sciences, Hiroshima University, Hiroshima, Japan.

Received, April 16, 2018; Revised, June 24, 2018; Accepted, June 28, 2018, Publishes, June 30, 2018.

\begin{abstract}
Purpose. Alveolar clearance of proteins, such as albumin, plays an essential role in recovery from lung injuries. Albumin is known to be oxidized by reactive oxygen species (ROS), leading to generation of advanced oxidation protein products (AOPP)-albumin in the alveolar lining fluid. In this study, we aimed to characterize the uptake of FITC-labeled AOPP-albumin (FITC-AOPP-albumin) into human alveolar epithelial cell line, A549. Methods. FITC-AOPP-albumin uptake into A549 cells and its effect of ROS generation was evaluated using fluorescence spectrometer and flow cytometry, respectively. Results. FITC-AOPP-albumin was taken up by A549 cells in a time- and temperature-dependent fashion, and showed saturation kinetics with a $\mathrm{K}_{\mathrm{m}}$ value of $0.37 \mathrm{mg} / \mathrm{mL}$. The uptake of FITC-AOPP-albumin was suppressed by phenylarsine oxide, a clathrin-mediated endocytosis inhibitor, but not by indomethacin and nystatin, caveolae-mediated endocytosis inhibitors, or 5-(N-ethyl-N-isopropyl) amiloride, a macropinocytosis inhibitor. AOPP-albumin induced ROS generation in A549 cells, suggesting that alveolar clearance of AOPP-albumin should be important to prevent further ROS generation. Conclusion. AOPP-albumin is transported into alveolar epithelial cells through clathrin-mediated endocytosis, which may be important to prevent further ROS generation.
\end{abstract}

This article is open to POST-PUBLICATION REVIEW. Registered readers (see "For Readers") may comment by clicking on ABSTRACT on the issue's contents page.

\section{INTRODUCTION}

The surface of alveolar region is composed of two main cell types: the alveolar type I and type II cells. Type I epithelial cells covering approximately 90 $95 \%$ of the alveolar surface area are squamous cells, and play a fundamental role in gas change (1). Type II epithelial cells are cuboidal in shape and occupy $5-10 \%$ of the surface area (1). Additionally, type II epithelial cells have secretory organelles called lamellar bodies that are crucial for surfactant production and secretion (2).

There are various proteins including albumin, immunoglobulin $\mathrm{G}(\operatorname{IgG})$, $\operatorname{IgA}$, and transferrin in alveolar lining fluid $(1,3,4)$. In general, the albumin concentration under physiological condition is $5 \mathrm{mg} / \mathrm{mL}$, which is much lower than its concentration in plasma $(40 \mathrm{mg} / \mathrm{mL})$. However, the concentration of albumin in the alveolar fluid increases to $75-95 \%$ of the levels in plasma during pulmonary edema. Large quantities of insoluble proteins are observed in air spaces of patients with acute respiratory distress syndrome (ARDS) (5). Therefore, alveolar clearance of proteins, such as albumin, is critical to the process of recovery from pulmonary edema.

In response to inflammatory stimuli in lung, lung cells, such as alveolar epithelial cells and activated macrophages, produce reactive oxygen species (ROS), which oxidize lung proteins and inhibit their function. Increasing levels of ROS decrease the levels of enzymes in the antioxidant defense system, including superoxide dismutase and catalase, as well as scavengers such as glutathione, and vitamin E and C $(6,7)$. During ARDS, inflammatory mediators such as cytokines, chemokines, and adhesion molecules indirectly mediate ROS production and lead to further damage (8). Albumin, an abundant and important circulating antioxidant, is oxidized by ROS, producing advanced oxidation protein products (AOPP)-albumin (9). This AOPP-albumin

\footnotetext{
Corresponding Author: Prof Mikihisa Takano, Department of Pharmaceutics and Therapeutics, Graduate School of Biomedical \& Health Sciences, Hiroshima University, 1-2-3 Kasumi, Minami-ku, Hiroshima 734-8553, Japan; E-mail: takanom@hiroshima-u.ac.jp
} 
production may occur when ROS are generated during lung injury, so alveolar clearance of AOPP-albumin may be important for recovery from pulmonary edema.

Clearance mechanisms for various peptides and proteins from the alveolar space have been widely investigated and transcytosis is suggested to be the primary mechanism of protein and peptide absorption across alveolar epithelial cells $(3,4)$. In addition, we have reported that albumin was taken up by endocytosis in human and rat alveolar epithelial cell lines, A549 and RLE-6TN, in addition to rat primary cultured alveolar epithelial cells (10-13). The uptake of albumin in these cells was inhibited by chlorpromazine and phenylarsine oxide, inhibitors of clathrin-mediated endocytosis. Inhibitors of caveolae-mediated endocytosis, such as indomethacin, methyl- $\beta$-cyclodextrin, and nystatin did not suppress the uptake of albumin into these cells. Furthermore, knockdown of clathrin heavy chain by siRNA in RLE-6TN cells significantly decreased its mRNA expression and cellular uptake of albumin, indicating that albumin is endocytosed into alveolar epithelial cells through the clathrin-mediated pathway, but not the caveolae-mediated pathway $(14,15)$. However, the transport of AOPP-albumin into alveolar epithelial cells is not well understood.

In this study, we prepared FITC-labeled AOPP-albumin (FITC-AOPP-albumin) from native albumin and investigated the mechanism underlying transport of AOPP-albumin into A549 cells. In addition, the effect of albumin and AOPP-albumin on ROS production was examined to address the role of albumin in the alveolar space and the importance of alveolar clearance of AOPP-albumin.

\section{MATERIALS and METHODS}

\section{Materials}

Dulbecco's modified Eagle medium (DMEM) and fetal bovine serum (FBS) were obtained from MP Biomedicals (Solon, OH, USA). Trypsin-EDTA and penicillin-streptomycin were purchased from Life Technologies (Carlsbad, CA, USA). 5-(N-ethyl-N-isopropyl) amiloride (EIPA), indomethacin, nystatin and phenylarsine oxide (PAO) were purchased from Sigma-Aldrich (St. Louis, MO, USA). Sodium azide $\left(\mathrm{NaN}_{3}\right)$ was purchased from Katayama Chemical Industries Co., Ltd (Osaka, Japan). 2-deoxy-D-glucose (2-DOG) was purchased from Kanto Chemical Co. (Tokyo,
Japan). All chemicals used in the experiments were of the highest purity commercially available.

\section{Cell culture}

A549 cells were cultured in DMEM containing 100 $\mathrm{IU} / \mathrm{mL}$ penicillin, $100 \mathrm{mg} / \mathrm{mL}$ streptomycin, and $10 \% \mathrm{FBS}$ in $5 \% \mathrm{CO}_{2}$ at $37^{\circ} \mathrm{C}$, and subcultured every 7 days using $1 \mathrm{mM}$ EDTA and $0.25 \%$ trypsin. The medium was replaced every 2 or 3 days.

Preparation of AOPP-albumin and fluorescein isothiocyanate (FITC)-labeled AOPP-albumin

BSA $(20 \mathrm{mg} / \mathrm{mL}$; fatty acid-free) and chloramine T (100 $\mathrm{mM})$ were dissolved in phosphate-buffer (62.8 $\mathrm{mM} \mathrm{Na}_{2} \mathrm{HPO}_{4} 12 \mathrm{H}_{2} \mathrm{O}, 3.92 \mathrm{mM} \mathrm{KH} \mathrm{PO}_{4} ; \mathrm{pH} 8.0$ ) by incubating for $1 \mathrm{~h}$ at $37^{\circ} \mathrm{C}$ with bubbling $95 \% \mathrm{O}_{2}$. Dialysis was performed for $24 \mathrm{~h}$ at $4^{\circ} \mathrm{C}$, followed by lyophilization to obtain dried powdered AOPP-albumin.

The AOPP-albumin was dissolved in $0.1 \mathrm{M}$ $\mathrm{Na}_{2} \mathrm{CO}_{3}-\mathrm{NaHCO}_{3}$ solution $(20 \mathrm{mg} / \mathrm{mL})$ and mixed with $15 \quad \mathrm{mM}$ FITC solution (1:2.5 AOPP-albumin:FITC). The mixture was incubated with shaking for $4 \mathrm{~h}$ at room temperature. The fraction with a fluorescence intensity of $500 \mathrm{~nm}$ (ex)/520 nm (em) was collected and dialyzed using a cellulose membrane for $24 \mathrm{~h}$ at $4^{\circ} \mathrm{C}$ for removal of free FITC. The resulting lyophilized powder was used as FITC-AOPP-albumin.

\section{Uptake studies}

A549 cells were seeded into 12 -well plates at a density of $10 \times 10^{4}$ cells per well, and grown for 6 days. After the culture medium was removed, each well was washed twice and preincubated with phosphate-buffered saline (PBS) $(137 \mathrm{mM} \mathrm{NaCl}, 3$ $\mathrm{mM} \mathrm{KCl}, 8 \mathrm{mM} \mathrm{Na}_{2} \mathrm{HPO}_{4}, 1.5 \mathrm{mM} \mathrm{KH}_{2} \mathrm{PO}_{4}, 0.5$ $\mathrm{mM} \mathrm{MgCl} 2$ and $0.1 \mathrm{mM} \mathrm{CaCl}_{2} ; \mathrm{pH} 7.4$ ) containing $5 \mathrm{mM}$ D-glucose (PBS-G) at $37^{\circ} \mathrm{C}$ for $10 \mathrm{~min}$. PBS-G buffer containing FITC-AOPP-albumin (20 $\mathrm{mg} / \mathrm{mL}$ ) was then put into each well and the cells were incubated at $37^{\circ} \mathrm{C}$ or $4^{\circ} \mathrm{C}$ for $30,60,90$, and $120 \mathrm{~min}$.

For the inhibition studies, A549 cells were preincubated for $10 \mathrm{~min}$ with or without inhibitors as follows: PBS, PBS-G, $5 \mathrm{mM} \mathrm{NaN}_{3}$ plus $2.5 \mathrm{mM}$ 2-deoxy-D-glucose in PBS, PAO $(5-20 \mu \mathrm{M})$ in PBS-G, $300 \mu \mathrm{M}$ indomethacin in PBS-G, $50 \mu \mathrm{M}$ nystatin in PBS-G, or $50 \mu \mathrm{M}$ EIPA in PBS-G buffer. After the preincubation buffer was removed, the cells were incubated with $0.5 \mathrm{~mL}$ PBS-G buffer containing FITC-albumin with or without the inhibitors. 
After the incubation buffer was aspirated, the cells were washed three times with $1 \mathrm{~mL}$ of ice-cold PBS. The cells were collected into $0.5 \mathrm{~mL}$ ice-cold PBS with a rubber policeman and the wells were rinsed with $0.5 \mathrm{~mL}$ ice-cold PBS for improving recovery of cells. Subsequent washes of the cells were performed by centrifugation at 9838 $\mathrm{x} g$ for $3 \mathrm{~min}$ at $4^{\circ} \mathrm{C}$ two times. After removal of the supernatant, the pellet was solubilized in 0.8 $\mathrm{mL}$ PBS containing $0.1 \%$ Triton X-100 without $\mathrm{CaCl}_{2}$ and $\mathrm{MgCl}_{2}$ at room temperature for $30 \mathrm{~min}$, then centrifugation at $5600 \mathrm{x} g$ for $3 \mathrm{~min}$. Fluorescent analysis at $500 \mathrm{~nm}(\mathrm{ex}) / 520 \mathrm{~nm}(\mathrm{em})$ and protein assay (Lowry method) were performed using the supernatant.

\section{Real-time PCR analysis}

Total RNA of A549 cells was extracted using a High Pure RNA Isolation Kit (Roche Diagnostics, Laval, QC). Reverse transcription of the total RNA into cDNA was performed using ReverTra Ace (TOYOBO, Osaka, Japan). Quantitative evaluation for indicated mRNA expression was performed by real-time PCR analysis using the CFX Connect ${ }^{\mathrm{TM}}$ Real-Time PCR Detection System (Bio-Rad Laboratories, Inc., Hercules, CA, USA) and the KAPA SYBR $^{\circledR}$ FAST qPCR Kit (NIPPON Genetics, Tokyo, Japan), as previously described (16). The primer sequences were as follows: $C D 36$ sense 5'-GCCTCTCCAGTTGAAAACCC-3', antisense 5'-ACACAGGTCTCCCTTCTTTGC-3'; SR-B1 (SCRAB1) sense 5'-GATCCCTATCCCCTTCTATCTCTCC-3', antisense

5'-CTTTTGTGCCTGAACTCCCTGTA-3'; human glyceraldehyde-3-phosphate dehydrogenase $(G A P D H)$ sense 5'-ACGGGAAGCTTGTCATCAAT-3', antisense 5'-TGGACTCCACGACGTACTCA-3'. The mRNA expression level of GAPDH, a housekeeping gene, was used for normalization for that of each gene.

Transfection with siRNAs and uptake studies of FITC-AOPP-albumin

A549 cells were seeded into 12 -well plates at a density of $10 \times 10^{4}$ cells per well. After $24 \mathrm{~h}$, siRNAs specific for CD36 and SR-B1 (20 $\mathrm{pmol} / \mathrm{well})$ were transfected into the cells using Lipofectamine ${ }^{\mathbb{}} 2000$ (Thermo Fisher Scientific Inc., Massachusetts, USA), referring to the manufacturer's instructions. MISSION ${ }^{\circledR}$ siRNA Universal Negative Control (Sigma) was used as a control in an identical manner. After $72 \mathrm{~h}$, the efficiency of siRNA silencing was evaluated using the uptake study and real-time PCR analysis as described in sections of Uptake studies and Real-time PCR analysis, respectively.

\section{ROS detection by flow cytometry}

A549 cells were seeded into 12-well plates at a density of $10 \times 10^{4}$ cells per well. After $24 \mathrm{~h}$, the cells were treated with $1 \mathrm{mM} \mathrm{H} \mathrm{H}_{2} \mathrm{O}_{2}, 5 \mathrm{mg} / \mathrm{mL}$ albumin, or $5 \mathrm{mg} / \mathrm{mL}$ AOPP-albumin for $24 \mathrm{~h}$. In a second set of conditions, cells were treated with 0.5 $\mathrm{mM} \mathrm{H} \mathrm{O}_{2}$ for $24 \mathrm{~h}$, followed by incubation with 10 $\mathrm{mM} \mathrm{N}$-acetylcysteine (NAC) or $40 \mathrm{mg} / \mathrm{mL}$ albumin for $2.5 \mathrm{~h}$. Flow cytometry analysis was performed as previously described to detect ROS by measuring the fluorescence of 7'-dichlorofluorescein (DCF) (17).

\section{STATISTICAL ANALYSIS}

Mean \pm standard error of the mean (SEM) was given to each data. Statistically significant differences were determined by one-way ANOVA, followed by Tukey's test. Statistically significance was considerable when a $p$-value less than 0.05 .

\section{RESULTS}

General characteristics of FITC-AOPP-albumin uptake into A549 cells

To understand the general characteristics of AOPP-albumin uptake into A549 cells, the timeand temperature-dependence of FITC-AOPP-albumin $(5 \mathrm{mg} / \mathrm{mL})$ uptake were examined. FITC-AOPP-albumin uptake increased linearly up to $90 \mathrm{~min}$ at $37^{\circ} \mathrm{C}$ and the uptake was much lower at $4^{\circ} \mathrm{C}$ at all time points (Figure $1 \mathrm{~A}$ ). In addition, the uptake of FITC-AOPP-albumin in A549 cells was saturable and was mediated by a single transport system as evidenced by the linear Eadie-Hofstee plot (Figure 1B). The $\mathrm{V}_{\max }$ (maximum uptake rate) and $\mathrm{K}_{\mathrm{m}}$ (Michaelis constant) values were $1.4 \mu \mathrm{g} / \mathrm{mg}$ protein $/ 60 \mathrm{~min}$ and $0.37 \mathrm{mg} / \mathrm{mL}$, respectively.

Effect of unlabeled AOPP-albumin and metabolic inhibitors on FITC-AOPP-albumin uptake into A549 cells

FITC-AOPP-albumin $(5 \mathrm{mg} / \mathrm{mL})$ uptake into A549 cells was significantly inhibited by the co-treatment of the cells with unlabeled AOPP-albumin (20 $\mathrm{mg} / \mathrm{mL}$ ) (Figure 2), indicating that a specific 
transport system is associated with the uptake into A549 cells. In addition, pretreatment with metabolic inhibitors, $\mathrm{NaN}_{3}$ plus 2-DOG,

(A)

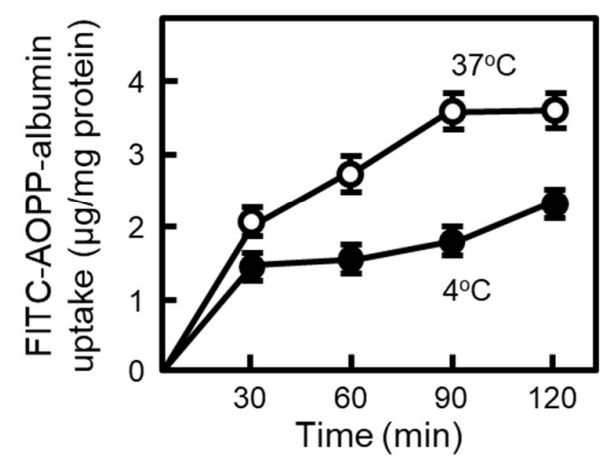

significantly decreased FITC-AOPP-albumin uptake to $69 \%$ of the control uptake (Figure 2 ).

(B)

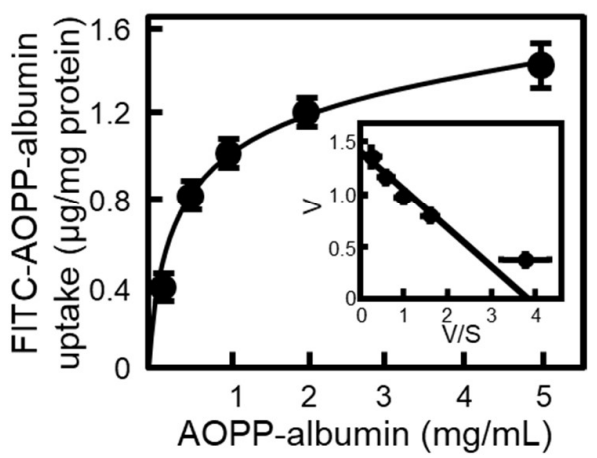

Figure 1. General characteristics of FITC-AOPP-albumin uptake into A549 cells. (A) The cells were incubated with FITC-AOPP-albumin $(5 \mathrm{mg} / \mathrm{mL})$ for $30,60,90$, and $120 \mathrm{~min}$ at $37^{\circ} \mathrm{C}$ (open circles) or $4^{\circ} \mathrm{C}$ (close circles). (B) The cells were incubated with FITC-AOPP-albumin $(0.1,0.5,1,2,5 \mathrm{mg} / \mathrm{mL})$ for $60 \mathrm{~min}$ at $37^{\circ} \mathrm{C}$ or $4^{\circ} \mathrm{C}$. The plot represents the specific uptake, found by subtracting the uptake at $4{ }^{\circ} \mathrm{C}$ from the uptake at $37^{\circ} \mathrm{C}$. The inset shows an Eadie-Hofstee plot. Each point represents the mean $\pm \operatorname{SEM}(n=3)$.

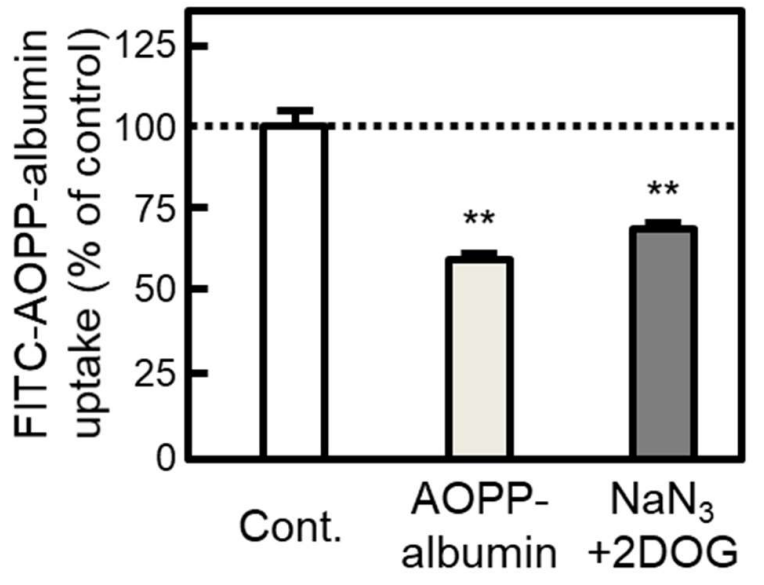

Figure 2. Effect of unlabeled AOPP-albumin and metabolic inhibitors on FITC-AOPP-albumin uptake into A549 cells. The cells were incubated with FITC-AOPP-albumin $(5 \mathrm{mg} / \mathrm{mL})$ in the absence or presence of unlabeled AOPP-albumin $(20 \mathrm{mg} / \mathrm{mL})$ or $\mathrm{NaN}_{3}(5 \mathrm{mM})$ and 2-deoxy-D-glucose (2-DOG) (2.5 $\mathrm{mM})$. Each value represents the mean $\pm \operatorname{SEM}(\mathrm{n}=3)$. Significant differences from the values found in the control cells are indicated as $* * p<0.01$.

\section{Role of scavenger receptors in} FITC-AOPP-albumin uptake into A549 cells As several reports have demonstrated that AOPP-albumin is one of the ligands for CD-36 and
SR-B1which are members of scavenger receptor class B, we focused on the role of these receptors in FITC-AOPP-albumin uptake into A549 cells. Transfection of A549 cells with siRNA specific for CD-36 and SR-B1 induced a significant decrease in the mRNA expression of CD-36 and SR-B1 to $31 \%$ and $22 \%$, respectively, as compared to transfection with control siRNA (Figure 3A). Using these CD36 and SR-B1 knockdown cells, the uptake of FITC-AOPP-albumin ( $5 \mathrm{mg} / \mathrm{mL})$ was examined. We found that the siRNA-mediated knockdown of CD36 and SR-B1 had no effect on FITC-AOPP-albumin uptake into A549 cells (Figure 3B).

\section{FITC-AOPP-albumin uptake into A549 cells via endocytic pathway}

We examined the possible endocytic pathway involved in FITC-AOPP-albumin uptake into A549 cells using various endocytosis inhibitors. PAO, an inhibitor of clathrin-mediated endocytosis, induced a significant decrease in FITC-AOPP-albumin uptake, in a concentration-dependent manner (Figure 4A). On the other hand, FITC-AOPP-albumin uptake was not affected by nystatin and indomethacin, which are inhibitors of caveolae-mediated endocytosis, or by EIPA, a macropinocytosis inhibitor (Figure 4B). 
(A)

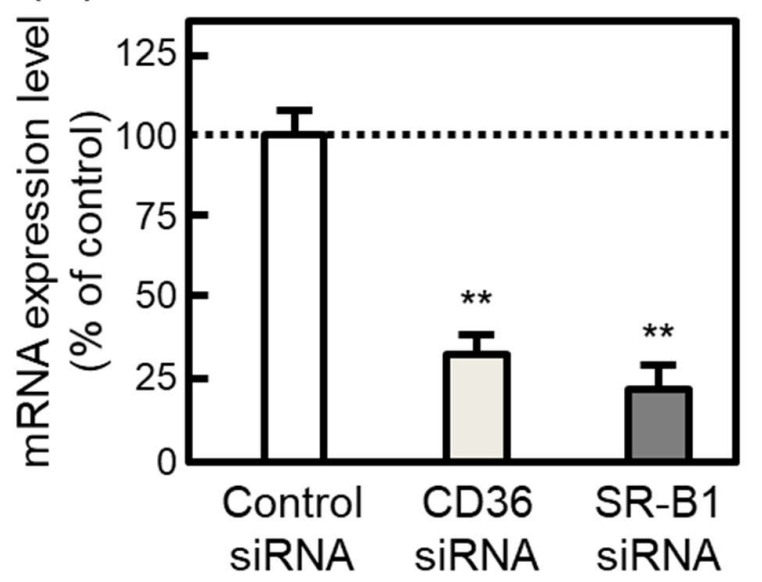

(B)

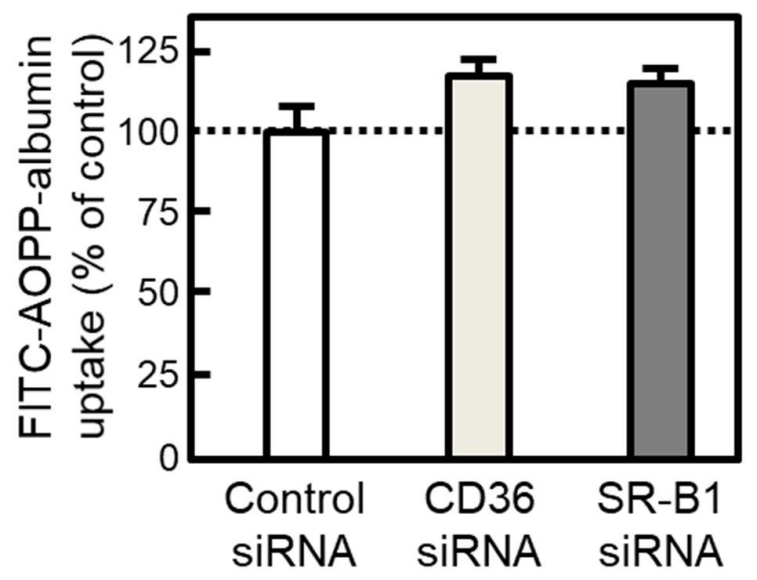

Figure 3. Role of scavenger receptors in FITC-AOPP-albumin uptake into A549 cells. MISSON ${ }^{\circledR}$ negative control, CD36-specific, or SR-B1-specific siRNA were transfected into A549 cells using Lipofectamine ${ }^{\circledR}$ 2000. (A) Real-time PCR analysis was performed $72 \mathrm{~h}$ after the transfection. (B) The cells were incubated with FITC-AOPP-albumin (5 $\mathrm{mg} / \mathrm{mL})$ for $60 \mathrm{~min}$ at $37^{\circ} \mathrm{C}$. Each value represents the mean $\pm \operatorname{SEM}(\mathrm{n}=3)$. Significant differences from the values found in the control cells are indicated as $* * p<0.01$.

(A)

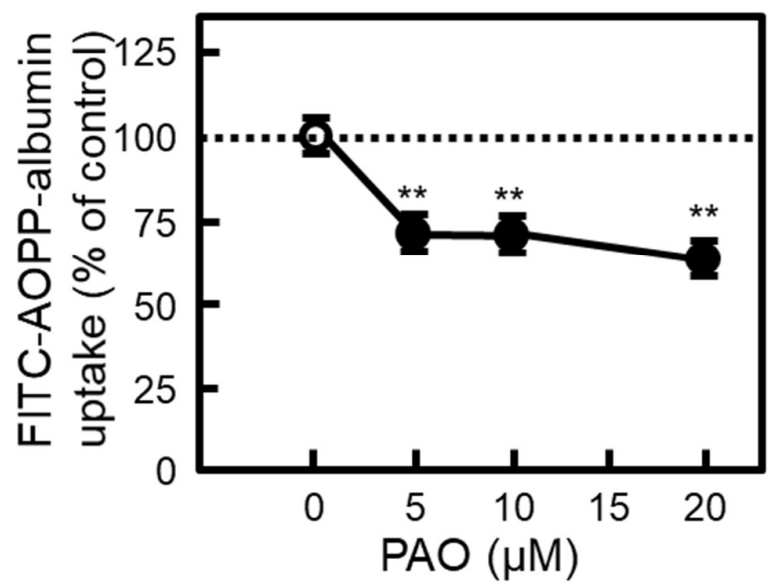

(B)

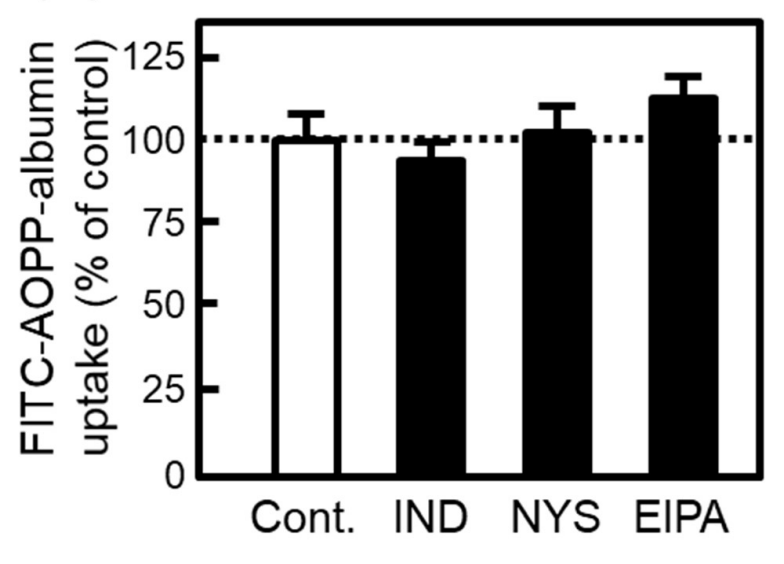

Figure 4. Endocytic pathway of FITC-AOPP-albumin uptake into A549 cells. (A) The cells were incubated with FITC-AOPP-albumin in the absence or presence of various concentrations of phenylarsine oxide $(\mathrm{PAO})(5,10,20 \mu \mathrm{M})$ for $60 \mathrm{~min}$ at $37^{\circ} \mathrm{C}$. (B) The cells were incubated with FITC-AOPP-albumin in the absence or presence of indomethacin (IND) $(300 \mu \mathrm{M})$, nystatin (NYS) $(50 \mu \mathrm{M})$, or 5-(N-ethyl-N-isopropyl) amiloride (EIPA) (50 $\mu \mathrm{M})$. Each value represents the mean $\pm \operatorname{SEM}(\mathrm{n}=3)$. Significant differences from the values found in the control cells are indicated as $* * p<0.01$.

Effect of albumin and AOPP-albumin on ROS generation in A549 cells

Considering that ROS production is associated with lung injuries, such as pulmonary edema, it is important to recognize the regulation of ROS generation by albumin and AOPP-albumin. As such, the effect of AOPP-albumin and albumin on ROS generation in A549 cells was examined. As shown 
in Figure 5A, treatment of A549 cells with $\mathrm{H}_{2} \mathrm{O}_{2}(1$ $\mathrm{mM})$, a ROS inducer, or AOPP-albumin $(5 \mathrm{mg} / \mathrm{mL})$ for $24 \mathrm{~h}$ significantly increased the intracellular level of ROS, while albumin did not affect the level of ROS. The effect of albumin on $\mathrm{H}_{2} \mathrm{O}_{2}$-induced enhancement of ROS generation in A549 cells was also examined by treatment of A549 cells with $\mathrm{H}_{2} \mathrm{O}_{2}(0.5 \mathrm{mM})$ for $24 \mathrm{~h}$, followed by incubation with albumin $(40 \mathrm{mg} / \mathrm{mL})$ or NAC $(10 \mathrm{mM})$, a ROS scavenger, for $2.5 \mathrm{~h}$. Both albumin and NAC significantly suppressed the elevation in ROS levels induced by $\mathrm{H}_{2} \mathrm{O}_{2}$ in $\mathrm{A} 549$ cells (Figure 5B).

\section{DISCUSSION}

It is well established that alveolar fluid clearance is markedly impaired in most patients suffering from ARDS and this impairment is associated with worse outcomes (18). In addition, the excess alveolar fluid clearance is an active metabolic process concerning vectorial transport of $\mathrm{Na}^{+}$with water out of alveolar air space, following the osmotic gradient (19). $\mathrm{Na}^{+}$transport from the apical surface to alveolar epithelial cells is associated with amiloride-sensitive $\mathrm{Na}^{+}$channels $(\mathrm{ENaC})$ and in part, by other, less well-characterized cationic channels $(20,21)$. Thus, the mechanism underlying alveolar fluid clearance mediated by $\mathrm{Na}^{+}$transport is becoming clearer. Although clearance of various proteins from the alveolar space is important for the recovery from pulmonary edema, limited information is available on the mechanisms, especially for proteins other than albumin $(15,22)$. In this study, the transport of AOPP-albumin, an oxidized albumin product, into A549 cells was investigated.

FITC-labeled AOPP-albumin was taken up by A549 cells in a time- and temperature-dependent manner and the uptake showed saturation kinetics, with $V \max$ and $\mathrm{K}_{\mathrm{m}}$ values of $1.3 \mu \mathrm{g} / \mathrm{mg}$ protein $/ 60$ min and $0.3 \mathrm{mg} / \mathrm{mL}$, respectively. Our previous report demonstrated that albumin uptake was mediated by two types of transport systems in A549 cells, low and high affinity transport systems with $\mathrm{K}_{\mathrm{m}}$ values of $5 \mathrm{mg} / \mathrm{mL}$ and $0.15 \mathrm{mg} / \mathrm{mL}$, respectively (10). In this study, AOPP-albumin uptake by a single transport system was suggested by an Eadie-Hofstee plot, indicating that a high affinity transport system for albumin uptake may be involved in AOPP-albumin uptake into A549 cells. Anraku et al. have reported that chloramine-T induced oxidation of not only a cysteine residue (Cys34), but also of methionine residues at positions 298, 329 and 446 in subdomain IIA of albumin (23). These changes may suppress the low affinity transport system-mediated AOPP-albumin uptake in A549 cells.

(B)

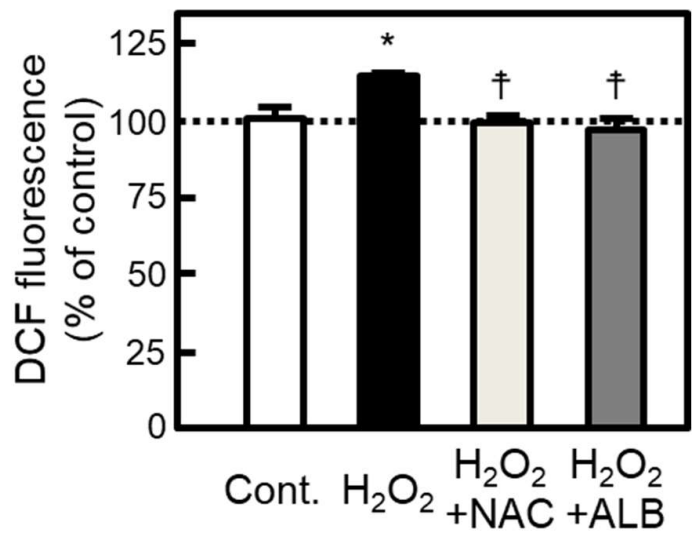

Figure 5. Effect of albumin and AOPP-albumin on ROS generation in A549 cells. (A) The cells were incubated with $\mathrm{H}_{2} \mathrm{O}_{2}(1 \mathrm{mM})$, albumin $(5 \mathrm{mg} / \mathrm{mL})$, or AOPP-albumin $(5 \mathrm{mg} / \mathrm{mL})$ for $24 \mathrm{~h}$. (B) The cells were incubated with $\mathrm{H}_{2} \mathrm{O}_{2}(0.5$ $\mathrm{mM})$ for $24 \mathrm{~h}$, then incubated with NAC $(10 \mathrm{mM})$ or albumin $(40 \mathrm{mg} / \mathrm{mL})$ for $2.5 \mathrm{~h}$. After the above-mentioned treatments, intracellular ROS levels were detected by measuring the fluorescence of 7'-dichlorofluorescein (DCF) using flow cytometry. Each value represents the mean $\pm \operatorname{SEM}(n=3)$. Significant differences from the values found in the control cells are indicated as $* p<0.05$. Significant differences from the values found in the $\mathrm{H}_{2} \mathrm{O}_{2}$-treated cells are indicated as ${ }^{\dagger} p<0.05$. 
Several types of scavenger receptors, including human scavenger receptor class A (SR-A), which binds LDL, and CD36 are shown to bind to modified albumin $(24,25)$. Iwao et al. clearly demonstrated the specific cell association of ${ }^{125}$ I-AOPP-HSA in Chinese hamster ovary (CHO) cells with overexpression of CD36, but not in mock-CHO cells (26). In addition, Marsche et al. clarified that AOPP-albumin interferes with clearance of plasma HDL cholesterol mediated by SR-B1 in mice (27). However, in this study, knockdown of CD36 and SR-B1 in A549 cells had no effect on the FITC-AOPP-albumin uptake. Therefore, other types of scavenger receptors are likely to be involved in AOPP-albumin uptake into A549 cells. As oxidized albumin is known to contain a structural motif similar to advanced glycation end products (AGEs), the receptors associated with AGEs may be involved in AOPP-albumin transport into A549 cells $(28,29)$. Further studies are needed to identify the receptor responsible for transport of AOPP-albumin into A549 cells.

In this study, we found that FITC-AOPP-albumin uptake was inhibited by a clathrin-mediated endocytosis inhibitor, while caveolae-mediated endocytosis and micropinocytosis inhibitors did not affect the uptake of FITC-AOPP-albumin into A549 cells. Therefore, clathrin-mediated endocytosis is mainly associated with AOPP-albumin transport into A549 cells. We previously demonstrated that albumin was taken up by clathrin-mediated, but not by caveolae-mediated, endocytosis into A549 cells (10). In addition, albumin uptake into A549 cells was almost completely inhibited by AOPP-albumin (data not shown), indicating that AOPP-albumin may be taken up by a similar transport system to that for albumin. Although the association of SR-B1 with AOPP-albumin was not observed in this study, the shared binding site on SR-B1 for albumin and AOPP-albumin has been observed (27). Therefore, there may be a common endocytosis receptor with a site that can bind to both albumin and AOPP-albumin.

In immortalized rat intestinal epithelial cells, AOPPs induced ROS generation, followed by epithelial cell death, with an increase in expression level of apoptosis-related proteins and phosphorylation of c-jun N-terminal kinase (30). In this study, we showed that AOPP-albumin enhanced ROS generation in A549 cells, which would aggravate lung diseases, such as ARDS.
To evaluate the inhibitory effect of native albumin on $\mathrm{H}_{2} \mathrm{O}_{2}$-induced ROS generation, we performed post-treatment of A549 cells with native albumin after $\mathrm{H}_{2} \mathrm{O}_{2}$ treatment and found an antioxidant effect of native albumin in A549 cells. The method used was based on a previous study showing that co-incubation of albumin with $\mathrm{H}_{2} \mathrm{O}_{2}$ induced a great loss of free thiols in albumin after $75 \mathrm{~min}$ (31). We also observed that co-treatment with native albumin had no effect on the $\mathrm{H}_{2} \mathrm{O}_{2}$-induced increase in ROS generation (data not shown).

One of the important roles of serum albumin is its redox buffering action. In albumin, the Cys34 residue with free thiol has significant antioxidant activity. Thus, the ratio of the oxidized/unoxidized form of albumin, a function of the redox state of Cys34, could serve as one of effective markers for monitoring disease progression and therapeutic efficacy (32). The antioxidant effect of albumin, seen in this study, may induce Cys34 oxidation in albumin and the detection of the modified albumin in bronchoalveolar lavage fluid (BALF) could aid in diagnosis of several lung diseases.

In the acute lung injury mouse model developed by exposing to aerosolized liposaccharide, increased levels of ROS and albumin were detected in the BALF (33). In addition, albumin is known to be oxidized by ROS, producing AOPP-albumin (9). These facts suggest that conversion of albumin to AOPP-albumin by ROS would occur under in vivo conditions. Therefore, AOPP-albumin clearance from alveolar space should be important not only to enhance excess fluid clearance from the lung, but also to prevent the progression of lung disease. Further studies are necessary to clarify the detailed mechanism of AOPP-albumin transport and its physiological and pathophysiological role in lung alveoli.

\section{CONCLUSION}

The uptake of AOPP-albumin in the alveolar epithelial cell line, A549, was examined. FITC-labeled AOPP-albumin uptake in A549 cells was time- and temperature-dependent, and saturable. In addition, we found that FITC-AOPP-albumin uptake was mediated by clathrin-mediated endocytosis into A549 cells, but not by caveolae-mediated endocytosis or macropinocytosis. Furthermore, the present results showed that AOPP-albumin increased ROS 
generation, while albumin had an antioxidant effect, indicating the importance of AOPP-albumin clearance from alveolar space. Although identification of AOPP-albumin receptor(s) was not achieved in this study, it is important to further clarify the molecular mechanisms underlying AOPP-albumin transport into alveolar epithelial cells.

\section{ACKNOWLEDGEMENT}

We thank Ms. A. Aoki and S. Taniguchi for their assistance at the initial stage of this study.

\section{CONFLICT OF INTEREST STATEMENT}

The authors declare that there are no conflicts of interest.

\section{REFERENCES}

1. Patton JS. Mechanisms of macromolecule absorption by the lungs. Adv Drug Deliv Rev, 1996;19: 3-36. DOI: https://doi.org/10.1016/0169-409X(95)00113-L

2. Fehrenbach H. Alveolar epithelial type II cell: defender of the alveolus revisited. Respir Res, 2001; 2:33-46. DOI: https://doi.org/10.1186/rr36

3. Kim K-J, Malik AB. Protein transport across the lung epithelial barrier. Am J Physiol Lung Cell Mol Physiol, 2003; 284:L247-259. DOI: https://doi.org/10.1152/ajplung.00235.2002

4. Hastings RH, Folkesson HG, Matthay MA. Mechanisms of alveolar protein clearance in the intact lung. Am J Physiol Lung Cell Mol Physiol, 2004; 286:L679-689. DOI: https://doi.org/10.1152/ajplung.00205.2003

5. Clark JG, Milberg JA, Steinberg KP, Hudson LD. Type III procollagen peptide in the adult respiratory distress syndrome. Association of increased peptide levels in bronchoalveolar lavage fluid with increased risk for death. Ann Intern Med, 1995; 122:17-23.

DOI: https://doi.org/10.7326/0003-4819-122-1-19950101 0-00003

6. Ware LB. Pathophysiology of acute lung injury and the acute respiratory distress syndrome. Semin Respir Crit Care Med, 2006; 27:337-349. DOI: https://doi.org/10.1055/s-2006-948288

7. Ciencewicki J, Trivedi S, Kleeberger SR. Oxidants and the pathogenesis of lung diseases. J Allergy Clin Immunol, 2008; 122:456-470. DOI: https://doi.org/10.1016/j.jaci.2008.08.004

8. Bhatia M, Moochhala S. Role of inflammatory mediators in the pathophysiology of acute respiratory distress syndrome. J Pathol, 2004;
202:145-156.

DOI:

https://doi.org/10.1002/path.1491

9. Roche M, Rondeau P, Singh NR, Tarnus E, Bourdon E. The antioxidant properties of serum albumin. FEBS Lett, 2008; 582:1783-1787. DOI: https://doi.org/10.1016/j.febslet.2008.04.057

10. Yumoto R, Suzuka S, Oda K, Nagai J, Takano M. Endocytic uptake of FITC-albumin by human alveolar epithelial cell line A549. Drug Metab Pharmacokinet, 2012; 27:336-343. DOI: https://doi.org/10.2133/dmpk.DMPK-11-RG-127

11. Yumoto R, Nishikawa H, Okamoto M, Katayama H, Nagai J, Takano M. Clathrin-mediated endocytosis of FITC-albumin in alveolar type II epithelial cell line RLE-6TN. Am J Physiol Cell Mol Physiol, 2006; 290:L946-L955. DOI: https://doi.org/10.1152/ajplung.00173.2005

12. Tagawa M, Yumoto R, Oda K, Nagai J, Takano M. Low-affinity transport of FITC-albumin in alveolar type II epithelial cell line RLE-6TN. Drug Metab Pharmacokinet, 2008; 23:318-327. DOI: https://doi.org/10.2133/dmpk.23.318

13. Ikehata $M$, Yumoto $R$, Nakamura $K$, Nagai J, Takano M. Comparison of albumin uptake in rat alveolar type II and type I-like epithelial cells in primary culture. Pharm Res, 2008; 25:913-922. DOI: https://doi.org/10.1007/s1 1095-007-9426-X

14. Takano M, Ryoko Y. Transport of proteins and peptides and its regulation in alveolar epithelial cells. Membrane, 2011; 36:145-153. DOI: https://doi.org/10.5360/membrane.36.145

15. Takano M, Kawami M, Aoki A, Yumoto R. Receptor-mediated endocytosis of macromolecules and strategy to enhance their transport in alveolar epithelial cells. Expert Opin Drug Deliv, 2015; 12:813-825.

DOI: https://doi.org/10.1517/17425247.2015.992778

16. Kawami M, Harabayashi R, Miyamoto M, Harada R, Yumoto R, Takano M. Methotrexate-induced epithelial-mesenchymal transition in the alveolar epithelial cell line A549. Lung, 2016; 194:923-930. DOI: https://doi.org/10.1007/s00408-016-9935-7

17. Kawami M, Deguchi J, Yumoto R, Sakakibara N, Tsukamoto I, Konishi R, Takano M. Effect of $\mathrm{COA}-\mathrm{Cl}$ on transforming growth factor- $\beta 1$-induced epithelial-mesenchymal transition in RLE/Abca3 cells. Drug Metab Pharmacokinet, 2017; 32:224-227. DOI: https://doi.org/10.1016/j.dmpk.2017.05.001

18. Ware LB, Matthay MA. Alveolar fluid clearance is impaired in the majority of patients with acute lung injury and the acute respiratory distress syndrome. Am J Respir Crit Care Med, 2001; 163:1376-1383. DOI: https://doi.org/10.1016/j.dmpk.2017.05.001

19. Mutlu GM, Sznajder JI. Mechanisms of pulmonary edema clearance. Am J Physiol Lung Cell Mol Physiol, 2005; 289:L685-695. DOI: https://doi.org/10.1152/ajplung.00247.2005 
20. Berthiaume Y, Lesur O, Dagenais A. Treatment of adult respiratory distress syndrome: plea for rescue therapy of the alveolar epithelium. Thorax, 1999; 54:150-160.

DOI: http://dx.doi.org/10.1136/thx.54.2.150

21. Trac PT, Thai TL, Linck V, Zou L, Greenlee M, Yue Q, AI-Khalili O, Alli AA, Eaton AF, Eaton DC. Alveolar nonselective channels are ASIC $1 \mathrm{a} / \alpha-\mathrm{ENaC}$ channels and contribute to AFC. Am J Physiol Cell Mol Physiol, 2017; 312:L797-L811. DOI: https://doi.org/10.1152/ajplung.00379.2016

22. Hastings RH, Folkesson HG, Matthay MA. Mechanisms of alveolar protein clearance in the intact lung. Am J Physiol Lung Cell Mol Physiol, 2004; 286:L679-689. DOI: https//doi.org/10.1152/ajplung.00205.2003

23. Anraku M, Kragh-Hansen U, Kawai K, Maruyama T, Yamasaki Y, Takakura Y, Otagiri M. Validation of the chloramine-T induced oxidation of human serum albumin as a model for oxidative damage in vivo. Pharm Res 2003; 20:684-692. DOI: https://doi.org/10.1023/A:1023219420935

24. Neeper M, Neeper M, Schmidt AM, Brett J, Yan SD, Wang F, Pan YC, Elliston K, Stern D, Shaw A. Cloning and expression of a cell surface receptor for advanced glycosylation end products of proteins. J Biol Chem, 1992; 267:14998-15004.

25. Ohgami N, Nagai R, Ikemoto M, Arai H, Kuniyasu A, Horiuchi S, Nakayama H. Cd36, a member of the class b scavenger receptor family, as a receptor for advanced glycation end products. J Biol Chem, 2001; 276:3195-3202. DOI: https://doi.org/10.1074/jbc.M006545200

26. Iwao Y, Nakajou K, Nagai R, Kitamura K, Anraku M, Maruyama T, Otagiri M. CD36 is one of important receptors promoting renal tubular injury by advanced oxidation protein products. Am J Physiol Renal Physiol, 2008; 295:F1871-1880. DOI: https://doi.org/10.1152/ajprenal.00013.2008

27. Marsche G, Frank S, Hrzenjak A, Holzer M, Dirnberger S, Wadsack C, Scharnagl H, Stojakovic
T, Heinemann A, Oettl K. Plasma-advanced oxidation protein products are potent high-density lipoprotein receptor antagonists in vivo. Circ Res, 2009; 104:750-757. DOI: https://doi.org/10.1161/CIRCRESAHA.108.193169

28. Witko-Sarsat V, Friedlander M, Capeillere-Blandin C, Nguyen-Khoa T, Nguyen AT, Zingraff J, Jungers $\mathrm{P}$, Descamps-Latscha B. Advanced oxidation protein products as a novel marker of oxidative stress in uremia. Kidney Int, 1996; 49:1304-1313. DOI: https://doi.org/10.1038/ki.1996.186

29. Witko-Sarsat V, Friedlander M, Nguyen Khoa T, Capeillere-Blandin C, Nguyen AT, Canteloup S, Dayer JM, Jungers P, Drueke T, Descamps-Latscha B. Advanced oxidation protein products as novel mediaters of inflammation and monocyte activation in chronic renal failure. J Immunol, 1998; 161:2524-2532.

30. Xie F, Sun S, Xu A, Zheng S, Xue M, Wu P, Zeng $\mathrm{JH}$, Bai L. Advanced oxidation protein products induce intestine epithelial cell death through a redox-dependent, c-jun $\mathrm{N}$-terminal kinase and poly (ADP-ribose) polymerase-1-mediated pathway. Cell Death Dis, 2014; 5:e1006. DOI: https://doi.org/10.1038/cddis.2013.542

31. Carballal S, Radi R, Kirk MC, Barnes S, Freeman BA, Alvarez B. Sulfenic acid formation in human serum albumin by hydrogen peroxide and peroxynitrite. Biochemistry, 2003; 42:9906-9914. DOI: https://doi.org/10.1021/bi027434m

32. Anraku M. Elucidation of the mechanism responsible for the oxidation of serum albumin and its application in treating oxidative stress-related diseases. Yakugaku Zasshi, 2014; 134:973-979. DOI: https://doi.org/10.1248/yakushi.14-00166

33. Mehla K, Balwani S, Agrawal A, Ghosh B. Ethyl gallate attenuates acute lung injury through $\mathrm{Nrf} 2$ signaling. Biochimie, 2013; 95:2404-2414. DOI: https://doi.org/10.1016/j.biochi.2013.08.030 